\title{
PENGARUH KECERDASAN LOGIS-MATEMATIS DAN KECERDASAN MUSIKAL TERHADAP HIGHER ORDER THINKING SKILLS (HOTS)
}

\author{
Leonard $^{1}$, Nanda Novi Linda ${ }^{2}$ \\ ${ }^{1}$ Universitas Indraprasta PGRI \\ leonard@unindra.ac.id \\ ${ }^{2}$ Universitas Indraprasta PGRI \\ nandalindannl@gmail.com
}

\begin{abstract}
ABSTRAK
Penelitian ini bertujuan untuk menguji hipotesis mengenai pengaruh kecerdasan logismatematis dan kecerdasan musikal terhadap higher order thinking skills (HOTS). Metode yang digunakan dalam penelitian ini adalah metode survei kuantitatif. Penelitian ini melakukan analisis deskriptif dan menguji persyaratan data (uji normalitas, uji linieritas regresi, dan uji multikolinieritas), yang dilanjutkan dengan pengujian hipotesis menggunakan uji korelasi dan regresi ganda. Sampel penelitian diambil dari populasi terjangkau dengan membuang data outliers. Jumlah sampel setelah data outliers dihilangkan adalah 99 peserta didik SMP. Instrumen yang digunakan adalah lembar tes pilihan ganda untuk mengukur kecerdasan logis-matematis, lembar observasi langsung untuk mengukur kecerdasan musikal, dan lembar tes esai untuk mengukur HOTS. Dari hasil pengujian hipotesis diperoleh kesimpulan bahwa terdapat pengaruh positif yang signifikan kecerdasan logismatematis dan kecerdasan musikal secara bersama-sama terhadap HOTS. Selain itu, terdapat pengaruh positif yang signifikan kecerdasan logis-matematis terhadap HOTS dan tidak terdapat pengaruh yang signifikan antara kecerdasan musikal terhadap HOTS.
\end{abstract}

Kata Kunci: Kecerdaasan Logis-Matematis, Kecerdasan Musikal, Higher Order Thinking Skills.

\begin{abstract}
The aim of this study is to test a hypothesis that there is an influence of logical-mathematical intelligence to higher order thinking skills (HOTS). This study uses survey research method. This study employes descriptive analysis and data requirement test (normality test, regression linearity test, and multi-colinearity test), that followed by hypothesis test using correlation and multiple regression. The samples were taken from an affordable population by removing data outliers. The number of samples after eliminating outliers' data is 99 students of junior secondary school. Instruments used in the study are a multiple-choice test to measure logical-mathematical intelligence, direct observation sheet to measure musical intelligence, and problem essay sheet to measure HOTS. This study concludes that there is a positive influence that significant in logical-mathematical intelligence and musical intelligence to HOTS. In addition, there is a positive influence that significant in logical-mathematical intelligence to HOTS and there is no positive influence that significant in musical intelligence to HOTS.
\end{abstract}


Keywords: Logical-Mathematical Intelligence, Musical Intelligence, Higher Order Thinking Skills Format Sitasi: Leonard \& Linda. (2018). Pengaruh Kecerdasan Logis-Matematis dan Kecerdasan Musikal Terhadap Higher Order Thinking Skills (HOTS). KALAMATIKA Jurnal Pendidikan Matematika, 3(2), 193-208.

Penyerahan Naskah: 5 Februari 2018 || Revisi: 12 September 2018 || Diterima: 13 September 2018

\section{PENDAHULUAN}

Pendidikan adalah suatu proses yang harus dilalui semua orang untuk kelangsungan hidup. Pendidikan bermanfaat untuk membangun individu yang berilmu baik secara moral maupun pikiran. Perbowo \& Pradipta (2017) menyatakan bahwa melalui pendidikan, individu dapat memperoleh ilmu, pengetahuan, dan keterampilan guna meningkatkan kemampuan berpikir, berusaha, dan penguasaan teknologi. Oleh karena itu, individu yang berpendidikan akan mempengaruhi kemakmuran bangsa dan kemajuan suatu negara, serta menghasilkan negara yang besar (Leonard, 2012). Sistem pendidikan di Indonesia memasuki proses perkembangan secara terarah. Dari tahun ke tahun Indonesia membuat peraturan-peraturan baru dalam dunia pendidikan yang bertujuan untuk meningkatkan kualitas pendidikan di Indonesia. Pemerintah juga mengupayakan agar pendidikan menjadi hal pertama yang paling harus diperhatikan. Namun hasil dari upaya yang dilakukan pemerintah belum dapat dikatakan memuaskan. Hal tersebut ditunjukkan berdasarkan hasil survei yang dilaksanakan oleh PISA 2015, menunjukkan posisi Indonesia dalam bidang science, reading, dan mathematics berada pada urutan ke-62 dari 70 negara yang disurvei (OECD, 2018).

Salah satu cara meningkatkan kualitas pendidikan di Indonesia adalah dengan membiasakan peserta didik untuk belajar, baik secara individu maupun kelompok. Belajar merupakan kegiatan yang menentukan peserta didik dapat menguasai materi atau tidak. Pembelajaran yang diberikan guru kepada peserta didik akan mempengaruhi perkembangan peserta didik ke depannya. Terdapat beberapa mata pelajaran yang harus dikuasai peserta didik, salah satunya yaitu Matematika. Matematika merupakan salah satu mata pelajaran yang paling penting dalam proses pendidikan dan semua pengetahuan tentang segala sesuatu di alam semesta ini didasari oleh matematika (Rooney, 2008). Pelajaran matematika adalah mata pelajaran wajib yang diberikan pada setiap jenjang pendidikan sebagaimana yang dinyatakan dalam UU No. 20 tahun 2003 tentang Sistem Pendidikan Nasional, Pasal 37 ayat 1. Di 
dalamnya dijelaskan bahwa bahan-bahan kajian yang ada pada matematika seperti berhitung dan ilmu ukur yang dimaksudkan untuk mengembangkan logika dan kemampuan berpikir peserta didik. Jagals \& Van Der Walt (2016) mengungkapkan bahwa dalam matematika, kemampuan pemecahan masalah berbicara tentang sesuatu yang tidak terlihat, masalahmasalah di luar kebiasan yang membutuhkan kemampuan berpikir tingkat tinggi dan kemampuan metakognitif. Dari pendapat ini ditegaskan bahwa matematika merupakan pelajaran yang sangat penting, yang bertujuan meningkatkan kemampuan berpikir siswa, terutama dalam pemecahan masalah.

Secara umum, kemampuan matematis peserta didik di Indonesia masih belum seperti yang diharapkan. Hal ini ditunjukkan oleh hasil survei PISA (Programme for International Student Assesment), bahwa kemampuan anak Indonesia usia 15 tahun di bidang matematika, sains dan membaca, dibandingkan dengan anak-anak lain di dunia masih tergolong rendah. Dalam program penilaian yang diselenggarakan tiga tahunan itu menunjukan bahwa sejak tahun 2012 hingga 2015 Indonesia menempati peringkat 62 dari 70 negara yang berpartisipasi dalam tes tersebut (OECD, 2018). Hasil Trends International Mathematics and Science Study (TIMSS) yang diselenggarakan oleh International Association for The Evaluation of Education Achievement (IEA) pada tahun 1999 Indonesia berada pada peringkat 34 dari 48 negara, tahun 2003 Indonesia berada pada peringkat 35 dari 46 negara, tahun 2007 Indonesia berada pada peringkat 36 dari 49 negara dan pada tahun 2011 Indonesia berada pada peringkat 36 dari 40 negara (Murtiyasa, 2015). Hal ini menunjukan bahwa penyelesaian soal matematika dan IPA pada dimensi konten yang diberikan TIMSS belum dapat diselesaikan dengan baik. TIMSS mengembangkan domain isi dan kognitif dalam penilaian matematika. Domain isi untuk tingkat 4 meliputi bilangan, bentuk geometri dan pengukuran, serta penyajian data, sedangkan untuk grade 8 meliputi bilangan, aljabar, geometri, data dan peluang-peluang. Soalsoal yang dikembangkan dalam TIMSS mencakup empat ranah kognitif yakni pengetahuan tentang fakta dan prosedur, penerapan konsep, pemecahan masalah rutin, dan penalaran (Mullis \& Martin, 2013).

Hasil survei PISA dan TIMSS tersebut menunjukan bahwa kemampuan berpikir tingkat tinggi peserta didik khususnya pada pelajaran matematika masih tergolong rendah. Hal ini dikarenakan kurangnya penalaran, analisis, pemahaman, dan kurangnya kebiasaan peserta didik untuk melakukan latihan-latihan soal yang membutuhkan tingkat berpikir tinggi. Clark 
(2015) mengemukakan tiga tingkatan berpikir tingkat tinggi (Higher Order Thinking Skills) yaitu kemampuan berpikir kritis, kemampuan berpikir tingkat tinggi, dan kemampuan pemecahan masalah. Pada umumnya, soal-soal yang memuat tuntutan berpikir tingkat tinggi berkaitan dengan ranah kognitif yang termasuk dalam Taksonomi Bloom yang memfokuskan penguasaan C1 sampai C6 (Analisis, Evaluasi, dan Sintesis). Hal inilah yang membuat HOTS sangat dibutuhkan, karena para siswa dewasa ini dituntut untuk memiliki kemampuan pemecahan masalah yang baik (Abdullah, Rahman, \& Hamzah, 2017).

Salah satu solusi untuk mengembangkan HOTS adalah melalui kecerdasan yang dimiliki peserta didik. Kecerdasan yang dimaksud adalah kecerdasan majemuk. Howard Gardner adalah orang yang mengungkapkan mengenai teori kecerdasan majemuk atau Multiple Intelligences. Teori ini menyatakan bahwa setiap orang memiliki bermacam-macam kecerdasan, tetapi dengan kadar pengembangan yang berbeda. Kecerdasan merupakan suatu kumpulan kemampuan dan keterampilan yang ditumbuh kembangkan. Kecerdasan-kecerdasan tersebut diantaranya the linguistic and logical-mathematical intelligences; musikal intelligence; spatial intelligence; bodily-kinesthetic intelligence; and two forms of personal intelligence, one directed toward other persons, one directed towards oneself (Gardner, 2011).

Selain jenis-jenis kecerdasan yang telah diungkapkan oleh Gardner sebelumnya, ada pula kecerdasan spiritual, kecerdasan eksistensial dan moral yang dikandidatkan untuk masuk dalam kecerdasan majemuk. Terdapat dua macam kecerdasan yang termasuk kecerdasan majemuk yang dimiliki oleh peserta didik yaitu kecerdasan logis-matematis dan kecerdasan musikal. Kecerdasan logis-matematis menekankan kepada pemecahan soal-soal dengan menggunakan logika yang menuntut anak untuk menalar dan menganalisis terlebih dahulu persoalan yang ada, sedangkan kecerdasan musikal memberi keleluasaan peserta didik untuk mampu berimajinasi dan berpikir kreatif secara lebih luas, berpikir kritis lebih dalam, dan mampu memecahkan persoalan dengan perhitungan yang terirama. Dari seluruh uraian-uraian sebelumnya, maka penelitian untuk mengetahui pengaruh kecerdasan majemuk, khususnya kecerdasan logis-matematis dan kecerdasan musikal terhadap HOTS mutlak diperlukan.

\section{METODE PENELITIAN}

Metode yang digunakan dalam penelitian ini adalah metode survei dengan pengujian hipotesis menggunakan uji korelasi dan regresi ganda. Sebelum data diuji, terlebih dahulu 
dilakukan analisis deskriptif dan uji persyaratan data (uji normalitas, uji linieritas regresi dan uji multikolinieritas).

Desain penelitian ini dapat dilihat pada gambar 1. Dari gambar 1 terlihat bahwa ada 2 variabel bebas yang akan dicari hubungan dan pengaruhnya terhadap variabel terikat. Uji yang digunakan dalam desain penelitian ini adalah uji korelasi dan regresi ganda. Uji korelasi ganda untuk mengetahui kuatnya hubungan antara dua variabel yang dianalisis, perhitungannya mencakup perhitungan koefesien korelasi dan koefesien determinan. Selanjutnya, uji regresi ganda yang bertujuan untuk menduga besarnya pengaruh dari variabel bebas terhadap variabel terikat. Dalam penelitian ini menggunakan 3 variabel yakni $\mathrm{X}_{1}, \mathrm{X}_{2}$ dan $\mathrm{Y}$.

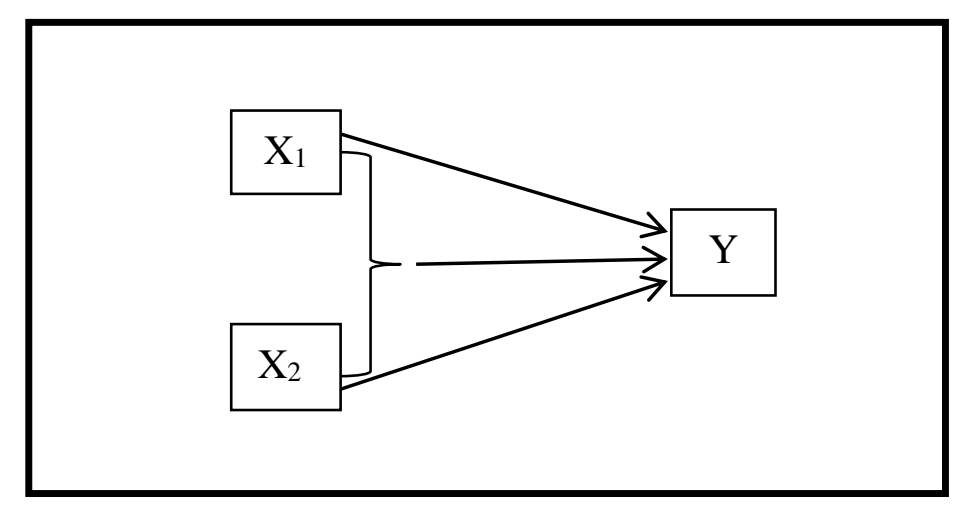

Gambar 1. Desain Penelitian

Keterangan:

$\mathrm{X}_{1}$ : Kecerdasan Logis-Matematis

$\mathrm{X}_{2}$ : Kecerdasan Musikal

Y : Higher Order Thinking Skills (HOTS)

Sampel yang digunakan dalam penelitian ini berjumlah 99 peserta didik, yang diambil dengan teknik simple random sampling dimana pengambilan sampel dari populasi secara acak tanpa memperhatikan strata tingkatan karena anggota populasi dianggap homogen. Teknik pengumpulan data yang digunakan untuk mengukur kecerdasan logis-matematis diperoleh dengan memberikan tes pilihan ganda, kecerdasan musikal diperoleh dari survei menggunakan lembar penilaian observasi, dan higher order thinking skills (HOTS) diperoleh dengan memberikan tes esai. Uji coba instrumen dilakukan pada kelas berbeda yang tidak dijadikan 
sampel. Peneliti mengambil dan menggunakan instrumen yang telah diuji validitas dan realibilitas sebelumnya tanpa memberikan perlakuan terhadap subjek penelitian.

\section{HASIL DAN PEMBAHASAN}

Secara deskriptif, data penelitian ini dapat dinyatakan dalam tabel 1.

Tabel 1. Statistik Deskriptif Kecerdasan Logis-Matematis, Kecerdasan Musikal dan Higher Order Thinking Skills (HOTS)

\begin{tabular}{lccc}
\hline $\begin{array}{c}\text { Statistik } \\
\text { Deskriptif }\end{array}$ & $\begin{array}{c}\text { Kecerdasan } \\
\text { Logis- } \\
\text { Matematis }\end{array}$ & $\begin{array}{c}\text { Kecerdasan } \\
\text { Musikal }\end{array}$ & $\begin{array}{c}\text { Higher Order } \\
\text { Thinking Skills } \\
(\text { HOTS })\end{array}$ \\
\hline Mean & 79,31 & 64,75 & 72,49 \\
Median & 81 & 61,67 & 74,64 \\
Modus & 81,09 & 57,35 & 76,50 \\
Varian & 193,95 & 222,25 & 231,50 \\
Simpangan Baku & 13,93 & 14,91 & 15,21 \\
\hline
\end{tabular}

Berdasarkan tabel 1 terlihat bahwa kecerdasan logis-matematis peserta didik tergolong baik, hal ini dapat dilihat dari mean, median, dan modus yang nilai pencapaiannya paling baik diantara hasil tes variabel lainnya. Kemudian, kecerdasan musikal peserta didik tergolong cukup, hal ini dapat dilihat dari mean, median, dan modus yang dicapai peserta didik. Sedangkan, higher order thinking skills terlihat bahwa nilai yang dicapai peserta didik cukup baik, hal ini dapat dilihat dari mean, median dan modus dalam variabel higher order thinking skills.

Peneliti melakukan pengujian persyaratan analisis data yang terdiri dari uji normalitas, uji linieritas, dan uji multikolinieritas. Pengujian normalitas dilakukan untuk mengetahui distribusi data setiap variabel berdistribusi normal atau tidak. Pengujian normalitas dilakukan dengan uji chi-kuadrat karena data disajikan dalam bentuk kelompok. Kriteria pengujian jika $\chi_{\text {hitung }}^{2}<\chi_{\text {tabel }}^{2}$ maka data berdistribusi normal, namun jika $\chi_{\text {hitung }}^{2}>\chi_{\text {tabel }}^{2}$ maka data tidak berdistribusi normal. Mencari $\chi_{\text {tabel }}^{2}$ dengan $\alpha=0,05$ dan $\mathrm{dk}=\mathrm{k}-1=7$ didapat $\chi_{\text {tabel }}^{2}=14,07$. Kesimpulan dari uji normalitas dari setiap variabel yang diteliti diringkas dalam tabel 2.

Tabel 2. Ringkasan Hasil Uji Normalitas

\begin{tabular}{lccc}
\hline \multicolumn{1}{c}{ Variabel } & $\chi_{\text {hitwng }}^{2}$ & $\chi_{\text {tabel }}^{2}$ & Keterangan \\
\hline Kecerdasan Logis-Matematis & 7,48 & 14,07 & Data Berdistribusi Normal \\
Kecerdasan Musikal & 10,14 & 14,07 & Data Berdistribusi Normal \\
Higher Order Thinking Skills $($ HOTS $)$ & 5,09 & 14,07 & Data Berdistribusi Normal \\
\hline
\end{tabular}

Pengujian linieritas dilakukan untuk menguji antara variabel bebas dengan variabel terikat dengan tujuan untuk mengetahui data berpola linier atau tidak. Pengujian linieritas 
dilakukan dengan membandingkan $\mathrm{F}_{\text {hitung }}$ dengan $\mathrm{F}_{\text {tabel. }}$ Kriteria pengujian adalah jika $\mathrm{F}_{\text {hitung }}<$ $F_{\text {tabel }}$ maka data berpola linier, namun jika $F_{\text {hitung }}>F_{\text {tabel }}$ maka data tidak berpola linier. $F_{\text {tabel }}$ diperoleh dengan menggunakan $\alpha=0,05$. Kesimpulan dari uji linieritas yang diteliti diringkas dalam tabel 3.

Tabel 3. Ringkasan Hasil Uji Linieritas

\begin{tabular}{rccc}
\hline Variabel & $\mathrm{F}_{\text {hitung }}$ & $\mathrm{F}_{\text {tabel }}$ & Keterangan \\
\hline $\mathrm{X}_{1}$ terhadap Y & $-6,43$ & 1,82 & Data Berpola Linier \\
$\mathrm{X}_{2}$ terhadap Y & $-2,44$ & 1,62 & Data Berpola Linier \\
\hline
\end{tabular}

Pengujian multikolinieritas dilakukan untuk menguji hubungan antara variabel bebas yaitu kecerdasan logis_matematis dan kecerdasan musikal. Kriteria pengujian adalah jika Tol (Tolerance) $\leq 0,1$ atau nilai Variance Inflation Faktor (VIF) $\geq 10$ maka terdapat kolinearitas/multikolinieritas, namun jika nilai Tol (Tolerance) $\geq 0,1$ atau nilai VIF $\leq 10$ maka tidak terdapat kolinearitas/multikolinieritas. Kesimpulan dari uji multikolinieritas yang diteliti diringkas dalam tabel 4.

Tabel 4. Ringkasan Hasil Uji Multikoinieritas

\begin{tabular}{cccc}
\hline Variabel & VIF $_{\text {hitung }}$ & Kriteria VIF & Keterangan \\
\hline $\begin{array}{l}\text { Kecerdasan Logis-Matematis } \\
\text { dan Kecerdasan Musikal }\end{array}$ & 1,07 & 10 & $\begin{array}{c}\text { Tidak Terjadi } \\
\text { Multikolinieritas }\end{array}$ \\
\hline
\end{tabular}

Pengujian selanjutnya yaitu pengujian hipotesis penelitian dengan menggunakan teknik analisis korelasi dan regresi ganda. Pengujian ini dilakukan dengan mencari koefisien korelasi ganda, koefisien determinasi ganda, persamaan regresi ganda, uji signifikasi regresi ganda dan uji parsial. Hasil dari koefisien korelasi ganda didapat nilai 0,39 dengan mencari terlebih dahulu nilai $r_{Y 1}, r_{Y 2}$ dan $r_{12}$. Kemudian koefisien korelasi ganda antara kecerdasan logismatematis $\left(\mathrm{X}_{1}\right)$ dan kecerdasan musikal $\left(\mathrm{X}_{2}\right)$ dengan higher order thinking skills $(\mathrm{Y})$ sebesar 0,39 tergolong lemah. Kontribusi variabel $\mathrm{X}_{1}$ dan $\mathrm{X}_{2}$ secara bersama-sama terhadap $\mathrm{Y}$ hanya sebesar $15,21 \%$ sedangkan $84,79 \%$ ditentukan oleh faktor lain.

Berdasarkan perhitungan uji regresi ganda diperoleh persamaan regresi ganda yaitu $\hat{\mathrm{Y}}=40,34+0,4 X_{1}+0,003 X_{2}$. Hal ini menunjukan jika kecerdasan logis-matematis dan kecerdasan musikal diabaikan, maka higher order thinking skills 40,34. Setiap penambahan 1 poin pada kecerdasan logis-matematis akan menambah higher order thinking skills sebesar 0,4 dan setiap penambahan 1 poin pada kecerdasan musikal akan menambah higher order thinking skills sebesar 0,003. Hasil uji signifikasi regresi ganda menunjukkan bahwa $F_{\text {hitung }}>F_{\text {tabel }}(8,17$ $>3,09$ ) maka dapat disimpulkan terdapat pengaruh positif yang signifikan kecerdasan logis- 
matematis $\left(\mathrm{X}_{1}\right)$ dan kecerdasan musikal $\left(\mathrm{X}_{2}\right)$ secara bersama-sama terhadap higher order thinking skills $(\mathrm{Y})$. Kemudian dilakukan uji parsial $\mathrm{X}_{1}$ terhadap $\mathrm{Y}$ dengan mengendalikan $\mathrm{X}_{2}$ menunjukkan bahwa $t_{\text {hitung }}>t_{\text {tabel }}(4>1,658)$ maka dapat disimpulkan bahwa terdapat pengaruh positif yang signifikan kecerdasan logis-matematis $\left(\mathrm{X}_{1}\right)$ terhadap higher order thinking skills $(\mathrm{Y})$, Sedangkan uji parsial $\mathrm{X}_{2}$ terhadap $\mathrm{Y}$ dengan mengendalikan $\mathrm{X}_{1}$ menunjukkan bahwa $t_{\text {hitung }}<\mathrm{t}_{\text {tabel }}(0,03<1,658)$ maka dapat disimpulkan bahwa tidak terdapat pengaruh positif yang signifikan kecerdasan musikal $\left(\mathrm{X}_{2}\right)$ terhadap higher order thinking skills (Y).

Mengacu dari hasil perhitungan, dapat dibuktikan bahwa kecerdasan logis-matematis dan kecerdasan musikal secara bersama-sama memberikan pengaruh positif terhadap kemampuan berpikir tingkat tinggi (higher order thinking skills). Namun jika dilihat dari perhitungan masing-masing variabel, kecerdasan logis-matematis memiliki pengaruh yang signifikan terhadap kemampuan berpikir tingkat tinggi, sedangkan kecerdasan musikal tidak memiliki pengaruh signifikan terhadap kemampuan berpikir tingkat tinggi.

Jika dilihat dari kontribusi kecerdasan logis-matematis dan kecerdasan musikal secara bersama-sama, ternyata hanya memberikan kontribusi yang tidak terlalu besar. Sekalipun hal ini tetap membuktikan bahwa kecerdasan logis-matematis dan kecerdasan musikal secara bersama-sama mempengaruhi kemampuan berpikir tingkat tinggi yang dimiliki peserta didik, khususnya kecerdasan logis-matematis yang memiliki peran yang cukup tinggi dalam peningkatan kemampuan berpikir tingkat tinggi. Peserta didik yang memiliki kecerdasan logis-matematis dan kecerdasan musikal secara bersamaan akan meningkatkan kemampuan berpikir tingkat tinggi.

Kecerdasan logis-matematis pada umumnya lebih menggunakan otak kiri dalam berpikir karena otak kiri secara tidak langsung menuntut peserta didik untuk berpikir secara matematis dengan menggunakan penalaran yang logis, mengurutkan cara yang benar dalam menghadapi suatu masalah, berpikir dalam pola sebab akibat, menciptakan hipotesis terlebih dahulu, mencari keteraturan konseptual atau pola numerik dan pandangan hidupnya bersifat rasional. Di masa depan, akan ada banyak perubahan yang akan dihadapi oleh manusia dan tentunya masalah yang dihadapi akan lebih kompleks dan berat, sehingga membutuhkan kemampuan yang besar dalam pemecahan masalah (Kim \& Kim, 2016). 
Menurut Yunus (2014) pola berpikir otak kiri menggunakan logika untuk mencari hubungan sebab akibat dan konvergensi yang bergerak menuju ke satu titik, atau denga kata lain masalah harus diperinci secara sistematis, dan berurutan. Karakteristik dan proses berpikir secara logis-matematis tersebut sangat berhubungan dengan kemampuan berpikir tingkat tinggi karena dalam kemampuan berpikir tingkat tinggi peserta didik harus mampu menggunakan penalaran dan logika agar dapat menyelesaikan soal dengan benar dan tepat. Leonard (2013) lebih lanjut menambahkan bahwa pola berpikir logis telah dikenal sebagai salah satu cara paling efektif dalam kemampuan berpikir manusia. Hal ini menunjukkan bahwa proses berpikir dalam mengembangkan kemampuan berpikir tingkat tinggi juga kurang lebihnya hampir selaras dengan kecerdasan logis-matematis.

Terdapat faktor lain yang dipengaruhi oleh kecerdasan logis-matematis yaitu hasil belajar yang dicapai peserta didik. Hal ini dibuktikan oleh penelitian yang dilakukan beberapa peneliti yang membuktikan bahwa adanya pengaruh positif kecerdasan logis-matematis terhadap hasil belajar (Suhendri, 2011; Sukada, dkk, 2013). Namun terdapat faktor lain yang tidak memiliki interaksi secara signifikan dengan kecerdasan logis-matematis. Hal ini diungkapkan oleh Puspadewi (2012) yang menemukan bahwa tidak ada interaksi model pembelajaran dan kecerdasan logis matematis terhadap kemampuan pemecahan masalah matematika. Berdasarkan hasil penelitian yang dilakukan oleh beberapa peneliti dapat dibuktikan bahwa hasil belajar adalah faktor lain yang dapat dipengaruhi oleh kecerdasan logis-matematis yang dimiliki peserta didik.

Peserta didik yang memiliki kecerdasan musikal lebih menuntut peserta didik menggunakan otak kanannya dalam berpikir karena kecerdasan musikal dapat melatih peserta didik untuk lebih kreatif dalam mencari penyelesaian berbagai persoalan. Persoalan yang dihadapi peserta didik akan dapat diselesaikan dengan kemampuannya dalam menyerap atau mengidentifikasi masalah yang ada kemudian mencari jalan keluar dengan tidak hanya fokus pada satu jalan keluar saja, tetapi peserta didik akan mampu memberikan berbagai cadangan cara untuk menyelesaikan persoalan yang dihadapi. Peserta didik yang memiliki kecerdasan musikal pada dirinya akan mampu meningkatkan fungsi otak kanan dalam berpikir secara lebih luas dari pada sebelumnya. Menurut Yunus (2014) pola berpikir otak kanan menggunakan intuisi dan mencari cara baru dan lain dalam melihat masalah, bergerak keluar, tidak mesti berurutan, dan fleksibel. Pernyataan tersebut menjelaskan peserta didik yang 
memiliki kecerdasan musikal yang secara tidak langsung menggunakan otak kanannya dalam berpikir akan mampu menggunakan intuisinya, dapat mencari cara baru dengan langkahlangkah baru secara luas dalam menyelesaikan persoalan khususnya yang membutuhkan kreativitas yang tinggi, mampu bergerak keluar dengan melihat persoalan dari sisi lain yang berbeda, tidak harus berurutan atau sesuai prosedur dalam mencari langkah penyelesaian dalam suatu persoalan, dan fleksibel dalam berinteraksi dengan tujuan mencari sebab akibat dari persoalan tersebut.

Peserta didik yang memiliki kecerdasan musikal mampu menyelesaikan masalah tanpa terganggu dengan iringan musik atau bunyi apapun di sekitarnya sehingga peserta didik akan lebih bisa mengontrol kondisi lingkungannya agar tetap fokus dalam menyelesaikan persoalan matematika. Beberapa peneliti mendapatkan hasil-hasil menarik terkait kecerdasan musikal, di antaranya adanya peningkatan kecerdasan musikal pada anak yang memperoleh pembelajaran melalui gerak dan lagu (Widhianawati, 2011), begitu pula adanya pengaruh kecerdasan musikal terhadap hasil belajar piano mahasiswa (Simamora, 2016), dan juga hasil penelitian yang menunjukkan bahwa angklung dapat meningkatkan kecerdasan musikal siswa (Anas, 2016). Berdasarkan hasil-hasil penelitian tersebut dapat diketahui bahwa terdapat beberapa faktor lain yang dapat mempengaruhi kecerdasan musikal antara lain pembelajaran gerak dan lagu, pembelajaran piano dan angklung yang keduanya termasuk jenis alat musik.

Karakteristik dan proses berpikir secara lebih luas berkaitan dengan kemampuan berpikir tingkat tinggi tetapi tidak berpengaruh secara signifikan karena banyaknya faktorfaktor lain yang lebih mempengaruhi kemampuan berpikir tingkat tinggi. Menurut Susanti (2014) ada beberapa komponen lain yang dapat menantang pemikiran tingkat tinggi, yaitu situasi, keterampilan, dan hasil belajar. Hal ini menjelaskan bahwa terdapat beberapa faktor lain yang dapat lebih mempengaruhi kemampuan berpikir tingkat tinggi antara lain situasi kondisi lingkungan sekitar baik ketika sedang mengerjakan soal atau tidak, keterampilan dalam menyelesaikan persoalan yang menuntut menggunakan kemampuan berpikir tingkat tinggi, dan hasil yang dicapai oleh peserta didik selama melakukan pembelajaran baik formal maupun non formal.

Pengembangan kecerdasan logis-matematis dan kecerdasan musikal secara bersamasama akan sangat mempengaruhi kemampuan berpikir tingkat tinggi peserta didik. Hal ini dilihat dari penggunaan otak pada kecerdasan logis-matematis dan kecerdasan musikal, dalam 
kecerdasan logis-matematis peserta didik menggunakan otak kirinya dalam berpikir sedangkan kecerdasan musikal peserta didik menggunakan otak kananya dalam berpikir. Kemampuan berpikir tingkat tinggi mengkolaborasikan kemampuan otak kiri dan otak kanannya dalam berfikir yang berfungsi sebagai pengamat bentuk soal dengan menggunakan otak kiri dan sebagai pencari jalan keluar secara lebih luas dengan menggunakan otak kanan. Pada prinsipnya, HOTS diperlukan pada kasus matematika yang sifatnya non-rutin, artinya kasus yang membutuhkan pemecahan tertentu dan tidak dapat ditemukan dalam buku teks matematika manapun (Abdullah et al., 2017). Kemampuan berpikir tingkat tinggi akan meningkat jika adanya kesinambungan otak kiri dan otak kanan. Peserta didik yang memiliki kecerdasan logis-matematis dan kecerdasan musikal secara bersama-sama akan meningkatkan kemampuan berpikir tingkat tinggi begitupun peserta didik yang memiliki kecerdasan logismatematis akan meningkatkan kemampuan berpikir tingkat tinggi peserta didik karena penggunaan otak kiri lebih berperan dalam kemampuan berpikir tingkat tinggi. Namun, peserta didik yang hanya memiliki kecerdasan musikal tidak dapat mempengaruhi kemampuan berpikir tingkat tinggi yang dimiliki peserta didik.

\section{KESIMPULAN}

Berdasarkan hasil penelitian dan analisis data serta melalui pengujian hipotesis berupa uji signifikan korelasi sampai dengan regresi ganda, peneliti mengambil simpulan bahwa terdapat pengaruh positif secara bersama-sama kecerdasan logis-matematis dan kecerdasan musikal terhadap higher order thinking skills. Hal ini menunjukkan bahwa higher order thinking skills dapat dikembangkan dengan menggabungkan fungsi otak kiri dan otak kanan yang sangat berkaitan dengan kecerdasan logis-matematis dan kecerdasan musikal. Selanjutnya, terdapat pengaruh positif kecerdasan logis-matematis terhadap higher order thinking skills. Kecerdasan logis-matematis dapat dijadikan salah satu faktor untuk meningkatkan kemampuan berpikir tingkat tinggi. Pengembangan ini dengan cara menguasai karakteristik kecerdasan logis-matematis dengan menggunakan otak kiri sebagai alat untuk menyelesaikan permasalahan dalam meningkatkan kemampuan berpikir tingkat tinggi. Kemudian, tidak terdapat pengaruh positif kecerdasan musikal terhadap higher order thinking skills. Banyaknya faktor lain yang lebih berperan dalam peningkatan kemampuan berpikir tingkat tinggi membuat kecerdasan musikal tidak berperan secara signifikan. Hal ini 
disebabkan penggunaan hanya dengan otak kanan tidak cukup untuk meningkatkan higher order thinking skills.

\section{REKOMENDASI}

Peneliti menyampaikan saran untuk seluruh pihak terkait guna meningkatkan kemampuan berpikir tingkat tinggi peserta didik khususnya dalam bidang studi matematika agar semakin baik, yaitu untuk pemerintah, peneliti lanjutan, peserta didik, orang tua, guru, dan juga kepala sekolah. Pemerintah diharapkan dapat meningkatkan upaya-upaya pengembangan dalam dunia pendidikan agar kemampuan berpikir tingkat tinggi peserta didik meningkat. Peneliti-peneliti yang begerak dalam kajian serupa, agar lebih memaksimalkan teknik penelitian karya ilmiah dan lebih kritis dalam membahas permasalahan yang diperoleh dengan perhitungan-perhitungan yang benar dan tepat. Peserta didik, diharapkan dapat terus meningkatkan kecerdasan logis-matematis dan kecerdasan musikal dengan cara terus berlatih agar bakat dapat tersalurkan dengan baik. Orang tua peserta didik, diharapkan lebih memperhatikan kemampuan anaknya dan memberikan motivasi untuk terus meningkatkan kecerdasan logis-matematis dan kecerdasan musikal sesuai dengan bakat yang dimiliki oleh peserta didik. Guru, diharapkan dapat mengembangkan konsep-konsep pembelajaran dengan tujuan mengembangkan kecerdasan logis-matematis dan dapat menyalurkan bakat peserta didik secara maksimal dalam mengembangkan kecerdasaan musikal. Terakhir, kepala sekolah, diharapkan lebih meningkatkan kinerja sebagai pelayan masyarakat dalam dunia pendidikan dengan memberikan kebijakan-kebijakan baru guna meningkatkan kemampuan-kemampuan yang dimiliki peserta didik.

\section{REFERENSI}

Abdullah, A. H., Rahman, S. N. S. A., \& Hamzah, M. H. (2017). Metacognitive Skills of Malaysian Students in Non-Routine Mathematical Problem Solving. Bolema Rio Claro, 31(57), 310-322. http://doi.org/10.1590/1980-4415v31n57a15

Anas, M. A. (2016). Peningkatan Kecerdasan Musikal dalam Pembelajaran SBK Menggunakan Alat Musik Angklung pada Siswa Kelas IVB SD Negeri Sinduadi 1. Jurnal Pendidikan Guru Sekolah Dasar, 5(33), 3154-3163. 
Gardner, H. (2011). Multiple Intelligences: The Theory in Practice. New York: Basics Book.

Jagals, D., \& Van Der Walt, M. (2016). Enabling Metacognitive Skills for Mathematics Problem Solving: A Collective Case Study of Metacognitive Reflection and Awareness. African Journal of Research in Mathematics, Science and Technology Education, 20(2), 154-164. http://doi.org/10.1080/18117295.2016.1192239

Kim, B. H., \& Kim, J. (2016). Development and Validation of Evaluation Indicators for Teaching Competency in STEAM Education in Korea. Eurasia Journal of Mathematics, Science and Technology Education, 12(7), 1909-1924. http://doi.org/10.12973/eurasia.2016.1537a

Clark, D. R. (2015). Bloom's Taxonomy of Learning Domains. (Online), (www.nwlink.com/ donclark/hrd/bloom.html)

Leonard. (2012). Level of Appreciation, Self-Concept and Positive Thinking on Mathematics Learning Achievement. The International Journal of Social Sciences, 6(1), 10-17.

Leonard. (2013). Peran kemampuan berpikir lateral dan positif terhadap prestasi belajar evaluasi pendidikan. Cakrawala Pendidikan, 29(1), 54-63. http://dx.doi.org/10.21831/cp.v5i1.1259

Mullis, I. V. S \& M. D. Martin. (Eds.) (2013). TIMSS 2015 Assessment Frameworks. Retrieved from Boston College, TIMSS and PIRLS International Study Center, (Online), (http://.timssandpirls.bc.edu/timss2015/frameworks.html)

Murtiyasa, B. (2015). Tantangan Pembelajaran Matematika Era Global. Prosiding Seminar Nasional Matematika dan Pendidikan Matematika UMS, 28-47. (Online), (https://publikasiilmiah.ums.ac.id/bitstream/handle/11617/6005/28_47\%20PROF\%20B UDI\%20M.pdf)

OECD. (2018). PISA - Result in Focus - OECD 2018. (Online), (http://www.oecd.org/pisa/pisa-2015-results-in-focus.pdf) 
Perbowo, K. S. \& Pradipta, T. R. (2017). Pemetaan Kemampuan Pembuktian Matematis Sebagai Prasyarat Mata Kuliah Analisis Riil Mahasiswa Pendidikan Matematika. KALAMATIKA Jurnal Pendidikan Matematika, 2(1), 81-90. http://dx.doi.org/10.22236/KALAMATIKA.vol2no1.2017pp81-90

Puspadewi, K. R. (2012). Pengaruh Model Pembelajaran Ikrar Berorientasi Kearifan Lokal dan Kecerdasan Logis Matematis Terhadap Kemampuan Pemecahan Masalah Matematika. Jurnal Pendidikan dan Pembelajaran Matematika Indonesia, 1(2), 1-15.

Rooney, A. (2008). The Story of Mathematics. London: Arcturus Publishing Limited.

Simamora, D. (2016). Pengaruh Multimedia Pembelajaran dan Kecerdasan Musikal Terhadap Hasil Belajar Piano Mahasiswa Jurusan Pendidikan Seni Musik Universitas Negeri Medan. Disertasi Terpublikasi. Universitas Negeri Medan, (Online), (http://digilib.unimed.ac.id/21573/5/9.\%20NIM\%208136122010\%20CHAPTER\%20I.p df)

Suhendri, H. (2011). Pengaruh Kecerdasan Matematis-Logis dan Kemandirian Belajar terhadap Hasil Belajar Matematika. Formatif: Jurnal Ilmiah Pendidikan MIPA, 1(1), 2939.

Sukada, I. K., Sadia, W., \& Yudana, M. (2013). Kontribusi Minat Belajar, Motivasi Berprestasi dan Kecerdasan Logis Matematika Terhadap Hasil Belajar Matematika Siswa SMA Negeri 1 Kintamani. Jurnal Administrasi Pendidikan Indonesia, 4(1).

Susanti, E. (2014). Pendidikan Matematika Realistik Berbantuan Komputer untuk Meningkatkan Higher-Order Thinking Skills dan Mathematical Habits of Mind Siswa SMP. Universitas Pendidikan Indonesia, (Online), (www.repository.upi.edu/15873/)

Yunus, M. (2014). Mindset Revolution: Optimalisasi Potensi Otak Tanpa Batas. Yogyakarta: Jogja Bangkit Publisher.

Widhianawati, N. 2011. Pengaruh Pembelajaran Gerak dan Lagu Dalam Meningkatkan Kecerdasan Musikal dan Kecerdasan Kinestetik Anak Usia Dini (Studi Eksperimen 
Kuasi pada Anak Kelompok Bermain Mandiri SKB Sumedang). Jurnal Penelitian Pendidikan, Edisi Khusus (2), 220-228. 
